\title{
Treatment of gonococcal urethritis with a single dose of doxycycline monohydrate
}

\author{
MILTON G. MUTCHNICK \\ From the Department of Medicine, Yale University School of Medicine, New Haven, Connecticut, \\ and the Veterans Administration Hospital, West Haven, Connecticut, U.S.A.
}

The frequency of strains of Neisseria gonorrhoeae resistant to penicillin and tetracycline has necessitated the evaluation of other therapeutic agents in the treatment of gonorrhoea. Penicillin allergy, the route of administration, and the duration of treatment are other factors to be considered. The purpose of this study was to determine the efficacy of a single dose of $300 \mathrm{mg}$. doxycycline monohydrate (Vibramycin $₫)^{\star}$ in the treatment of uncomplicated gonorrhoea in men.

\section{Material and methods}

The patients studied were 51 servicemen between the ages of 18 and 35 years who attended the venereal disease clinic of the Public Health section at the U.S.A.F. Hospital, Luke AFB, Arizona. All infections had been contracted in the metropolitan Phoenix area or nearby Mexican border towns. Men returning from South-East Asia were not included.

Diagnosis was based on the presence of a urethral discharge showing Gram-negative intracellular diplococci in the smear and a positive culture on Thayer-Martin plates (Martin, Billings, Hackney, and Thayer, 1967). Specimens for culture were obtained by scraping the urethra with a 2-mm diameter platinum wire loop. Culture plates were incubated at $36^{\circ} \mathrm{C}$. in an atmosphere of 5 per cent. $\mathrm{CO}_{2}$ and were examined at 24 and 48 hours for typical Neisseria gonorrhoeae colonies. Those which were oxidase-positive and demonstrated Gram-negative diplococci were presumed to be $N$. gonorrhoeae. Forty patients satisfied these criteria; eleven others did not have positive cultures.

A single dose of $300 \mathrm{mg}$. doxycycline monohydrate was administered orally after food. The patients were then advised not to take alcohol for 24 hours and not to have sexual intercourse for at least 10 days. They were told to return on the third and tenth days for further smears and cultures.

Received for publication February 14, 1972

$\star$ Provided by Pfizer Laboratories
Those patients who demonstrated positive smears or cultures on follow-up and who denied renewed sexual contact were designated failures and received other treatment. Two patients initially had positive smears and cultures, but on the third day after treatment one had a positive smear and the other a positive culture. Both admitted repeated sexual contact since treatment; they were considered to have been re-infected and were excluded from the series of 51 patients evaluated.

Results of treatment (Table)

Forty men who initially had both positive smears and positive cultures were re-examined on both the third and tenth days. Of these, 29 ( 72.5 per cent.) were considered cured (Group I). Eleven men had positive smears and negative cultures at the initial visit but negative smears and cultures on the third and tenth days. If these cases are added to the 29 considered cured in Group I, the cure rate becomes 78.4 per cent. of the larger group of 51 patients (Group II).

One patient who had taken the tablets in a fasting state vomited several hours later. No further treatment was given and he subsequently had negative smears and cultures. No other untoward reactions were observed.

\section{Discussion}

The ideal therapeutic agent for the treatment of gonorrhoea is an inexpensive, nontoxic, readily absorbed drug which can be administered in a single oral dose and which always eradicates the disease. Recent reports have indicated that doxycycline monohydrate satisfies many of these requirements.

Tetracycline and some of its derivatives have provided adequate treatment in cases of uncomplicated gonococcal urethritis (McLone, Kiley, and Hackney, 1967; Thatcher, Pazin, and Domescik,

TABLE Results of treatment

\begin{tabular}{|c|c|c|c|c|c|c|c|c|c|c|c|}
\hline \multirow{3}{*}{ Group } & \multirow{3}{*}{$\begin{array}{l}\text { Total cases } \\
\text { treated }\end{array}$} & \multicolumn{2}{|c|}{ Before therapy } & \multicolumn{2}{|l|}{$3 r d$ day } & \multicolumn{2}{|l|}{$10 t h$ day } & \multicolumn{4}{|c|}{ Result } \\
\hline & & \multirow{2}{*}{$\begin{array}{l}\text { Positive } \\
\text { smear }\end{array}$} & \multirow{2}{*}{$\begin{array}{l}\text { Positive } \\
\text { culture }\end{array}$} & \multirow{2}{*}{$\begin{array}{l}\text { Positive } \\
\text { smear }\end{array}$} & \multirow{2}{*}{$\begin{array}{l}\text { Positive } \\
\text { culture }\end{array}$} & \multirow{2}{*}{$\begin{array}{l}\text { Positive } \\
\text { smear }\end{array}$} & \multirow{2}{*}{$\begin{array}{l}\text { Positive } \\
\text { culture }\end{array}$} & \multicolumn{2}{|c|}{ Cure } & \multicolumn{2}{|c|}{ Failure } \\
\hline & & & & & & & & No. & Per cent. & No. & Per cent. \\
\hline $\begin{array}{l}\text { I } \\
\text { II }\end{array}$ & $\begin{array}{l}40 \\
51\end{array}$ & $\begin{array}{l}40 \\
51\end{array}$ & $\begin{array}{l}40 \\
40\end{array}$ & $\begin{array}{l}2 \\
2\end{array}$ & $\begin{array}{l}7 \\
7\end{array}$ & $\begin{array}{l}2 \\
2\end{array}$ & $\begin{array}{l}4 \\
4\end{array}$ & $\begin{array}{l}29 \\
40\end{array}$ & $\begin{array}{l}72 \cdot 5 \\
78 \cdot 4\end{array}$ & $\begin{array}{l}11 \\
11\end{array}$ & $\begin{array}{l}27 \cdot 5 \\
21 \cdot 6\end{array}$ \\
\hline
\end{tabular}


1970). Cornelius (1970) recorded a cure rate of between 59 and 93 per cent. for a single oral dose of $1.5 \mathrm{~g}$. tetracycline hydrochloride and of between 85 and 100 per cent. for a $3 \mathrm{~g}$. dose in groups of 100 male patients located in six cities.

Tetracycline may cause gastrointestinal upsets and absorption may be variable; these disadvantages have hindered the general acceptance of this medication as a one-dose treatment.

Doxycycline monohydrate, even when given in smaller doses, produces blood levels of the antibiotic equal to or higher than those obtained with tetracycline hydrochloride or demethylchlortetracycline. Small doses produce high plasma levels with a prolonged half-life (Rosenblatt, Barrett, Brodie, and Kirby, 1966; Fabre, Pitton, and Kunz, 1966).

In general, other trials of doxycycline have yielded high cure rates. Gallai, Sylvestre, and Brault (1969) obtained a 94.7 per cent. cure rate with a single dose of $300 \mathrm{mg}$. in forty cases. A subsequent study using the same dose yielded a cure rate of 96 per cent. in 199 cases.

In a study by Domescik, McLone, Scotti, and Mackey (1969), 95.3 per cent. of 158 males with uncomplicated gonorrhoea were cured by a single oral dose of $250 \mathrm{mg}$. doxycycline.

A report from Sweden gave a 96.4 per cent. cure rate for 247 male and female patients treated with $300 \mathrm{mg}$. doxycycline and returning for at least two follow-up visits (Lidén, Hammar, Hillström, Wallin, and Ohman, 1971).

Lassus (1968) reported a cure rate of 94 per cent. for 64 patients who received a single dose of $300 \mathrm{mg}$. doxycycline but Gray, Phillips, and Nicol (1970) reported a failure rate of 12.7 per cent. for 94 male patients receiving $300 \mathrm{mg}$. doxycycline.

Masterton and Schofield (1972) demonstrated a failure rate of 6.4 per cent. of 94 patients with uncomplicated gonorrhoea who were followed up after receiving $300 \mathrm{mg}$. doxycycline in a single dose. In a more recent study from Australia, however, 53 per cent. of 49 patients receiving $300 \mathrm{mg}$. doxycycline in a single dose, were considered to be failures after an interval of 24 hours to 3 weeks (Baytch and Rankin, 1972).

The cure rate obtained in the present series is low and tends to support the findings of Baytch and Rankin (1972). Possibly some of the military personnel involved, who were considered to be treatment failures, had engaged in further sexual activity although this was denied. Alternatively some of them may have been infected with organisms resistant to tetracycline.

The results of this study indicate that a single oral dose of $300 \mathrm{mg}$. doxycycline monohydrate may be inadequate for the treatment of uncomplicated gonococcal urethritis.

\section{Summary}

Of 51 servicemen treated for acute gonorrhoea with a single dose of $300 \mathrm{mg}$. doxycycline monohydrate, forty (78.4 per cent.) were considered to be cured on the basis of negative smears and cultures after 3 and 10 days. If only the forty patients who initially had positive cultures as well as smears are considered, the cure rate was 72.5 per cent. In some parts of the world a single oral dose of $300 \mathrm{mg}$. doxycycline may now be inadequate.

\section{References}

BAYTCH, H., and RANkin, D. W. (1972) Brit. F. vener. Dis., 48, 129

CoRnelius, C. E. (1970) Ibid., 46, 330

Domescik, G., MCLoNe, D. G., SCotTi, A., and MACKeY, D. M. (1969) Publ. Hlth Rep. (Wash.), 84, 182

Fabre, J., Pitton, J. S., and Kunz, J. P. (1966) Chemotherapia (Basel), 11, 73

Gallai, Z., Sylvestre, L., and Brault, J. P. (1969) Presented at Second World Congress of International Society of Tropical Dermatology, Kyoto, Japan

Gray, R. C. F., Phillips, I., and Nicol, C. S. (1970) Brit. F. vener. Dis., 46, 401

Lassus, A. (1968) Chemotherapy, 13, 366

LIDÉN, S., HAMmar, H., Hillström, L., WALlin, J., and Öhman, S. (1971) Acta derm.-venereol. (Stockh.), 51, 221

Martin, J. E., Jr., Billings, T. E., Hackney, J. F., and Thayer, J. D. (1967) Publ. Hlth Rep. (Wash.), 82, 361

Masterton, G., and Schofield, C. B. S. (1972) Brit. F. vener. Dis., 48, 121

McLone, D. G., Kiley, J. D., and HackNey, J. F. (1967) Ibid., 43, 166

Rosenblatt, J. E., Barrett, J. E., Brodie, J. L., and KIRBY, W. M. (1966) Antimicrob. Agents Chemother., 6, 134

Thatcher, W., Pazin, G., and Domescik, G. (1970) Publ. Hlth Rep. (Wash.), 85, 160

Traitement de l'urétrite gonococcique par une dose unique de monohydrate de doxycycline

\section{SOMMAIRE}

Sur 51 hommes de troupe traités pour une gonococcie aigüe par une dose unique de $300 \mathrm{mg}$ de monohydrate de doxycycline, quarante $(78,4$ pour cent) furent considérés comme guéris au nom d'examens sur lame négatifs et de cultures négatives au 3ème et 10ème jour. Si l'on considère seulement les 40 malades qui avaient au départ aussi bien une culture positive qu'une lame positive, le taux de guérison est de 72,5 pour cent. Dans certaines parties du monde, une dose orale unique de $300 \mathrm{mg}$ de doxycycline peut maintenant être inappropriée. 